\title{
phoPQ carrying Salmonella in bile of cattle
}

\author{
Muammer GONCUOGLU ${ }^{1}$, N. Deniz AYAZ ${ }^{1}$, Lüppo ELLERBROEK ${ }^{2}$, F. Seda BILIR ORMANCI ${ }^{1}$, \\ Murat ULUDAG ${ }^{1}$ and Irfan EROL ${ }^{1}$
}

\author{
${ }^{1}$ Ankara University, School of Veterinary Medicine, Department of Food Hygiene and Technology, 06110, Diskapi, Ankara, \\ TURKEY. ${ }^{2}$ Federal Institute for Risk Assessment (BfR) FGr 42 - NRL for Campylobacter Diedersdorfer Weg 1 12277, Berlin, \\ GERMANY.
}

\begin{abstract}
Summary: The objectives of this study were to determine the prevalence of Salmonella in bile of cattle by comparing immunomagnetic separation (IMS) based cultivation and conventional cultivation techniques, to verify the isolates by the detection of oriC gene, to determine $p h o P Q$ gene by PCR, to identify the isolates by serotyping and to find out the antibiotic resistance profiles using disc diffusion method. A total of 188 cattle bile samples were collected from two slaughterhouses near Ankara between MaySeptember 2007. In three (1.6\%) of the samples Salmonella spp. were detected by IMS based cultivation technique and two (1.1\%) of the samples with conventional cultivation technique. It was shown that IMS based cultivation technique is more sensitive for the detection of Salmonella in bile of cattle. From the each contaminated samples three colonies were picked and coded (A, B and C). Isolates were verified by detection of oriC gene and $p h o P Q$ gene was detected using PCR. According to serotyping; two of them (A and B) were found to be $S$. Dublin and one (C) $S$. Bredeney. Disc diffusion method indicated that, $S$. Bredeney was resistant to ampicillin, cephalothin, tetracycline, nalidixic acid and sulphamethoxazole. All $S$. Dublin and $S$. Bredeney isolates were intermediately resistant to streptomycin, also $S$. Dublin to sulphamethoxazole and $S$. Bredeney to amoxicillin/clavulanic acid and cephazolin. In conclusion bile can be a site of Salmonella in cattle and all the isolates carried phoPQ gene that may play a significant role in the survival of Salmonella spp. in bile.
\end{abstract}

Key words: Antibiotic resistance, bile, cattle, IMS, PCR, PhoPQ, Salmonella, serotype.

\section{Sığır safrasında phoPQ taşıyan Salmonella}

Özet: Bu çalışmada, sığır safra örneklerinde Salmonella varlığının klasik kültür ve IMS (immuno-manyetik separasyon) yöntemleriyle tespit edilmesi, elde edilen izolatların PCR yöntemiyle oriC geni ile doğrulanması, phoPQ geninin belirlenmesi, izolatların serotiplendirilmesi ve antibiyotik direnç profillerinin belirlenmesi amaçlanmıştır. Bu amaçla 2007 yılı Mayıs-Eylül ayları arasında Ankara bölgesinde yer alan iki mezbahadan 188 sığır safra örneği toplanmıştır. Örneklerden 3 tanesi (\% 1.6) IMS ve 2 tanesi (\% 1.1) klasik kültür yöntemiyle Salmonella spp. olarak tespit edilmiştir. Sonuçlar ile sığır safrasında Salmonella'nın belirlenmesinde IMS bazlı kültür tekniğinin klasik kültür tekniğine gore daha duyarlı olduğu görülmektedir. Salmonella tespit edilen örneklerden 3'er koloni alınarak A, B ve C şeklinde kodlanmıştır. İzolatlar PCR yöntemiyle oriC ve phoPQ genleri yönünden analiz edilmiştir. Serotiplendirme işlemi sonucunda elde edilen izolatların ikisinin (A ve B) $S$. Dublin, birinin (C) $S$. Bredeney olduğu tespit edilmiştir. Disk difüzyon yöntemiyle $S$. Bredeney izolatının ampisilin, sefalotin, tetrasiklin, nalidiksik asit ve sülfametaksazole karşı dirençli olduğu tespit edilmiştir. Bütün izolatların (her iki $S$. Dublin ve $S$. Bredeney) streptomisine karşı, $S$. Dublin'in sülfametaksazole ve $S$. Bredeney'in amoksisilin/klavulanik asite karşı orta düzeyde dirençli olduğu belirlenmiştir. Sonuç olarak, sığır safralarının Salmonella yönünden önemli bir kaynak olabileceği ve izolatların taşıdığı phoPQ geninin Salmonella türlerinin safra koşullarında canlı kalmasında etkin rol oyanayabileceği belirlenmiştir.

Anahtar sözcükler: Antibiyotik direnç, IMS, PCR, phoPQ, safra, Salmonella, serotip, sığır.

\section{Introduction}

Salmonella, an important foodborne pathogen of zoonotic significance, has been associated with foods of animal origin (6). Salmonella has the ability to colonize the gallbladder where bile concentration is extremely high (4). Bile acids are derived from cholesterol in the liver and secreted into bile, which is stored in the gallbladder. Bile acids are also reabsorbed in the distal small intestine and large intestine following deconjugation by the resident microbial flora. Bile is produced as a sterile compound, but interacts with enteric bacteria following secretion into the duodenum (19). Bile represents a major challenge to survival and subsequent colonization of microorganisms in the gastrointestinal tract. Therefore the gallbladder should be considered as a potential source of enteric pathogens such as Salmonella and E. coli $\mathrm{O} 157: \mathrm{H} 7$ (4; 17; 22; 27). It was reported that, after invading to macrophages in intestine $S$. Typhi can transport to the liver and it can be shed into the gallbladder (30). 
Salmonella spp. encounter and must be able to resist the action of bile salts within the intestine. Enteric bacteria, including Salmonella spp., are resistant to the effects of bile (32). Previous studies revealed that a percentage (1 to $3 \%$ ) of individuals infected with Salmonella become chronic carriers and the prime location of the persistent infection is the gallbladder. In the carrier state, organisms are continuously released into the intestine and shed in the feces. It was reported that bile or gallbladder may play a role in the development of the carrier state (23).

Salmonellae are able to use bile as an environmental signal that effects its virulence by showing resistance to bile's emulsifying and antimicrobial characteristics (19). The outer membrane of Gram negative bacteria is thought to be the main barrier to bile salts (29). Also it was reported that PhoP-PhoQ (PhoPQ) regulated products play an important role in the survival of Salmonella spp. in the intestine and gallbladder (32) and also PhoPQ regulatory system is necessary for the virulence of Salmonella spp. $(18 ; 20)$.

A considerable number of antimicrobials commonly used in the treatment of salmonellosis and other bacterial infections of humans are also used in veterinary practices. This may present a public health risk by the transfer of resistant Salmonella and other zoonotic bacterial pathogens or the resistant genes from food animals to humans through consumption of contaminated food and food products $(16 ; 35)$. The increase of antimicrobial resistance in Salmonella and other bacterial pathogens have been a serious public health concern worldwide. Over the last two decades several multidrugresistant Salmonella serotypes causing human and animal disease, have emerged $(26 ; 33)$.

The aims of this study were to determine the prevalence of Salmonella in bile of cattle by comparing IMS based cultivation and conventional cultivation tecniques, to verify the isolates by the detection of oriC gene, to determine $p h o P / p h o Q$ ( $p h o P Q$ ) gene by PCR, to identify the isolates by serotyping and to find out the antibiotic resistance profiles using disc diffusion method.

\section{Material and Methods}

Sample design and collection: A total of 188 bile samples of cattle were obtained using sterile syringe from undamaged gallbladders of healthy animals after evisceration of carcasses from two different slaughterhouses near Ankara between May to September of 2007. Approximately $20 \mathrm{ml}$ of bile samples were taken into laboratory in an ice bag and analyzed in the same day.

Isolation and identification of Salmonella spp.: In the study conventional cultivation and immunomagnetic separation (IMS) based cultivation techniques were compared for the isolation of Salmonella from bile of cattle.
Conventional cultivation technique: ISO 6579 technique was used for the isolation of Salmonella (2). Ten $\mathrm{ml}$ of bile samples were weighted to sterile bags and enriched with $90 \mathrm{ml}$ Buffered Peptone Water (BPW, Oxoid CM1049, Hampshire, UK) and incubated at $37^{\circ} \mathrm{C}$ for 24 hours. Afterwards, aliquots of $0.1 \mathrm{ml}$ were transferred to $10 \mathrm{ml}$ of Rappaport-Vasilliadis Broth (RVB, Oxoid CM669), and $1 \mathrm{ml}$ to $9 \mathrm{ml}$ of Selenite Cystine Broth (SCB, Oxoid CM0699) supplemented with sodium biselenite (Oxoid LP0121) and incubated for 24 hours at $42^{\circ} \mathrm{C}$ and $37^{\circ} \mathrm{C}$, respectively. Following to the incubation broths were streak onto both of Brilliant-green Phenol-red Lactose Sucrose Agar (BPLS, Merck 1.07237, Hohenbrunn, Germany) and Xylose-Lysin Desoxycholate Agar (XLD, Oxoid CM0469). The plates were then incubated at $37^{\circ} \mathrm{C}$ for $24-48$ hours. One to three typical colonies grown were picked from each medium and inoculated into Triple Sugar Iron Agar (TSIA, Oxoid CM0277), Lysine Iron Agar (LIA, Oxoid CM0381) and Urea Broth Base (Merck 1.08483) supplemented with $40 \%$ of urea solution (Oxoid SR0020). The mediums were incubated at $37^{\circ} \mathrm{C}$ for $24-48$ hours. TSIA positive, LIA positive and urease negative colonies were considered as suspect Salmonella.

The agglutination test was done with omnivalent Salmonella antisera (Denka Seiken 055111, Tokyo, Japan). Agglutination with antiserum was accepted as a positive reaction for Salmonella spp. The isolates were stored at $4^{\circ} \mathrm{C}$ and $-20^{\circ} \mathrm{C}$ for further tests.

Immunomagnetic separation (IMS) Based Cultivation Method: Ten $\mathrm{ml}$ of bile samples were weighted to sterile bags and enriched with $90 \mathrm{ml}$ BPW (Oxoid CM1049) and incubated at $37^{\circ} \mathrm{C}$ for 24 hours. After the incubation period IMS was performed with $20 \mu \mathrm{l}$ of magnetic beads coated with specific antibody against Salmonella (Dynabeads anti Salmonella, Prod. No. 710.02, Dynal, Oslo, Norway) according to the manufacturer's protocol (1).

Serotyping: Serotyping of the Salmonella isolates were performed with the scheme of Kaufmann-White using lam aglutination and serum neutralization tests (25).

PCR analysis: In order to determine the origin of DNA Replication (oriC) $(37 ; 15 ; 12)$ and phoPQ (34) genes of Salmonella strains, PCR analysis were performed. For the PCR analysis Salmonella Typhimurium ATCC 14028 was used as positive control.

$D N A$ extraction: Isolates that stored at $4^{\circ} \mathrm{C}$ in Tryptone Soy Agar (TSA, Oxoid CM 131) were incubated in Brain Heart Infusion broth (BHI, Oxoid $\mathrm{CM} 0225$ ) at $37^{\circ} \mathrm{C}$ for $24 \mathrm{~h}$. Then $1 \mathrm{ml}$ of each enrichment culture was separately transferred to microcentrifuge tubes. All tubes were centrifuged (Eppendorf Centrifuge $5417 \mathrm{R}$, Hamburg, Germany) for $15 \mathrm{~min}$ at $5000 \mathrm{rcf}$ at $10^{\circ} \mathrm{C}$. The pellets were resuspended in $1 \mathrm{ml}$ sterile aquabidest. The suspensions were mixed by vortex (IKA MS1 Minishaker, Wilmington, USA). Then all tubes were centrifuged for $5 \mathrm{~min}$ at $5000 \mathrm{rcf}$ at $10^{\circ} \mathrm{C}$. The 
pellets were resuspended with $200 \mu \mathrm{l}$ sterile aquabidest and incubated for $20 \mathrm{~min}$ at $95^{\circ} \mathrm{C}$ in a water bath (Memmert WB/OB 7-45, WBU 45, Schwabach, Germany) then cooled on ice.

PCR analysis for the detection of oriC gene: OriC gene specific primers (primer 1: 5'- TTA TTA GGA TCG CGC CAG GC-3'; primer 2: 5'- AAA GAA TAA CCG TTG TTC AC-3') (Promega, Madison, WI, USA) that produce a $163 \mathrm{bp}$ DNA fragment were used for the verification of the Salmonella isolates $(37 ; 15 ; 12)$

PCR analysis for the detection of PhoPQ gene: Primers (337-L: 5'- ATG CAA AGC CCG ACC ATG ACG-3'; 338-R: 5'-GTA TCG ACC ACC ACG ATG GTT-3') (Promega) that produce a 299 bp DNA fragment and PCR conditions were used for the detection of $P h o P Q$ gene from Salmonella isolates according to the Way et al. (34).

Gel electrophoresis: A $10 \mu \mathrm{l}$ aliquot of each PCR product was subjected to $1.5 \%$ agarose gel $\left(\right.$ SeaKem ${ }^{\circledR}$ LE Agarose, Rockland, ME, USA) electrophoresis containing $0.1 \mu \mathrm{g} / \mathrm{ml}$ ethidium bromide for $1 \mathrm{~h}$ at $100 \mathrm{~V}$ (Biometra, Agagel-Maxi-System B15359). Amplicon visualization and documentation was performed using gel documentation and analysis system (Syngene Ingenius, Cambridge, UK).

Antimicrobial Susceptibility Tests: The antibiotic resistance tests of Salmonella isolates were carried out with the disc diffusion method as recommended by the Clinical and Laboratory Standards Institute (CLSI) (3) in Mueller-Hinton agar (Oxoid CM0337) with ampicillin (Oxoid CT0003B), cephazolin (Oxoid CT0011B), cephalothin (Oxoid CT0010B), gentamicin (Oxoid CT0794B), amikacin (Oxoid CT0107B), streptomycin (Oxoid CT0047B), tetracycline (Oxoid CT0054B), chloramphenicol (Oxoid CT0013B), amoxicillin/clavulanic acid (Oxoid CT0223B), cefoxitin (Oxoid CT0119B), ceftriaxone (Oxoid CT0417B), ciprofloxacin (Oxoid CT0425B), imipenem (Oxoid CT0455B), trimethoprim/ sulphamethoxazole (Oxoid CT0052B), kanamycin (Oxoid CT0026B), trimethoprim (Oxoid CT0076B), sulphonamide compounds (Oxoid CT0059B), ceftiofur (Oxoid CT1751B), nalidixic acid (Oxoid CT0031B), and sulphamethoxazole (Oxoid CT0051B).

\section{Results}

In the study, a total of 188 cattle bile samples were collected from two slaughterhouses near Ankara between May-September 2007. A total of three (1.6\%) samples were found positive for Salmonella. Within these positive isolates, using IMS based cultivation technique three cattle bile samples, by conventional cultivation technique two samples were found to be contaminated with Salmonella spp. From the each three Salmonella positive samples three colonies were picked and coded as $\mathrm{A}_{1}, \mathrm{~A}_{2}, \mathrm{~A}_{3}, \mathrm{~B}_{1}, \mathrm{~B}_{2}, \mathrm{~B}_{3}, \mathrm{C}_{1}, \mathrm{C}_{2}$ and $\mathrm{C}_{3}$, respectively (Table 1). In Salmonella detected bile's gallbladders, any abnormalities or gallstones were not observed.
PCR assay was performed for the verification (by the detection of oriC gene) and detection of phoPQ gene. From all isolates oriC and $p h o P Q$ genes were detected (Figure 1 and 2).

Tablo 1. Sığır safrasında Salmonella spp. varlığında kullanılan iki izolasyon yönteminin karşılaştırılması.

Table 1. Comparison of the two isolation methods for the incidence of Salmonella spp. in bile of cattle.

\begin{tabular}{lccl}
\hline Isolation method & $\begin{array}{c}\text { Tested } \\
\text { samples }\end{array}$ & $\begin{array}{c}\text { Salmonella } \\
\text { positive } \\
\text { samples (\%) }\end{array}$ & $\begin{array}{c}\text { Code of positive } \\
\text { samples and }\end{array}$ \\
\hline $\begin{array}{l}\text { Conventional } \\
\text { cultivation method }\end{array}$ & 188 & $2(1.1)$ & $131(S$. Dublin) \\
$\begin{array}{l}\text { IMS based } \\
\text { cultivation method }\end{array}$ & 188 & $3(1.6)$ & $143(S$. Dublin) \\
& & & 143 (S. Dublin) \\
& & & $147(S$. Bredeney) \\
\hline
\end{tabular}

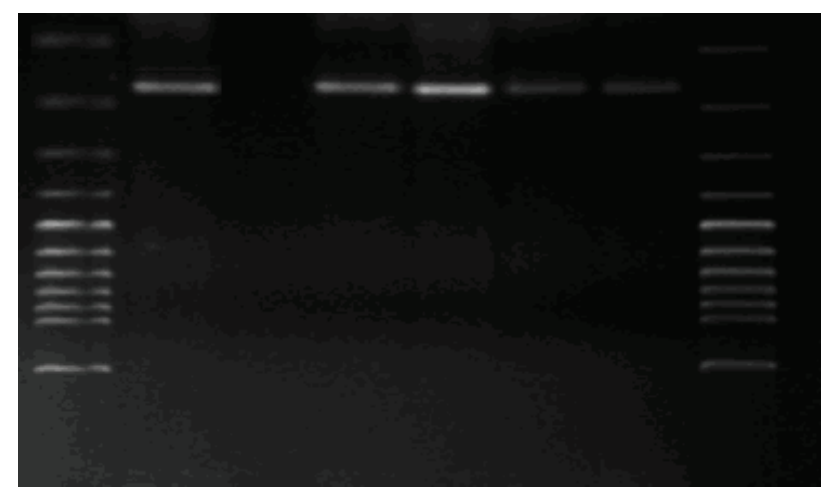

Fig. 1. OriC gene detected Salmonella spp. isolates by PCR. Lanes 1 and 8100 bp DNA marker; Lanes 2 and 7 Positive control - Salmonella Typhimurium ATCC 14028; Lanes 3 Negative control; Lanes 4 - 6 OriC positive Salmonella spp. isolates.

Şekil 1. Salmonella spp. izolatlarında PCR yöntemiyle oriC geninin tespiti. 1 ve 8 no'lu sütunlar DNA marker; 2 ve 7 no'lu sütunlar Pozitif kontrol - Salmonella Typhimurium ATCC 14028; 3 no'lu sütun Negatif kontrol; 4-5-6 oriC pozitif Salmonella izolatları.

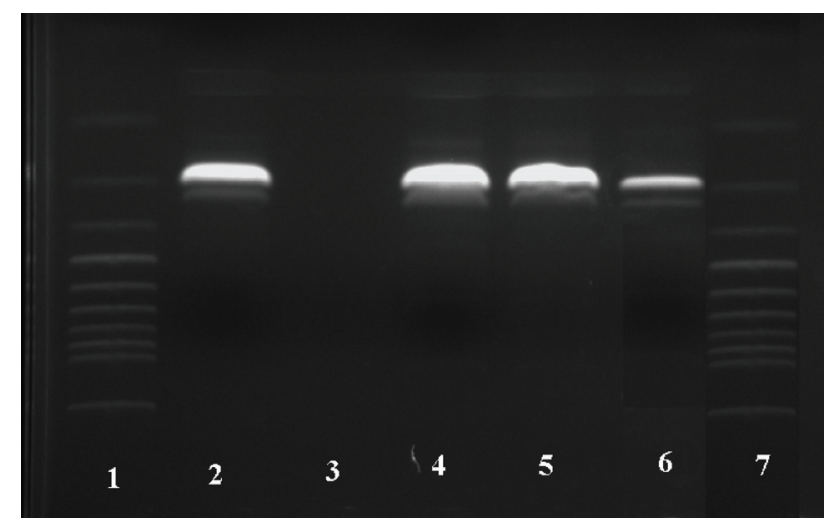

Fig. 2. PhoP/Q gene detected Salmonella spp. isolates by PCR. Lanes 1 and 7100 bp DNA marker; Lanes 2 Positive control Salmonella Typhimurium ATCC 14028; Lanes 3 Negative control; Lanes 4 - $6 \mathrm{PhoP} / \mathrm{Q}$ positive Salmonella spp. isolates.

Şekil 2. Salmonella spp. izolatlarında $p h o P / Q$ geni tespiti. 1 ve 7 no'lu sütunlar DNA marker; 2 no'lu sütun Pozitif kontrol Salmonella Typhimurium ATCC 14028; 3 no'lu sütun Negatif kontrol; 4-5-6 no'lu kuyucuklar $p h o P / Q$ pozitif Salmonella spp. izolatları. 
Table 2. Antibiotic resistance profiles of Salmonella isolates among the serotypes.

Tablo 2. Salmonella izolatlarının serotiplere göre antibiyotik direnç profilleri.

\begin{tabular}{|c|c|c|c|c|c|c|c|c|c|c|}
\hline \multirow[t]{2}{*}{ Antibiotics } & \multirow[t]{2}{*}{$\mu \mathrm{g} \operatorname{disc}^{-1}$} & \multicolumn{3}{|c|}{ S. Dublin } & \multicolumn{3}{|c|}{ S. Dublin } & \multicolumn{3}{|c|}{ S. Bredeney } \\
\hline & & $\mathrm{A}_{1}$ & $\mathrm{~A}_{2}$ & $\mathrm{~A}_{3}$ & $\mathrm{~B}_{1}$ & $\mathrm{~B}_{2}$ & $\mathrm{~B}_{3}$ & $\mathrm{C}_{1}$ & $\mathrm{C}_{2}$ & $\mathrm{C}_{3}$ \\
\hline Ampicillin & 10 & $\mathrm{~S}$ & $\mathrm{~S}$ & $\mathrm{~S}$ & $\mathrm{~S}$ & $\mathrm{~S}$ & $\mathrm{~S}$ & $\mathrm{R}$ & $\mathrm{R}$ & $\mathrm{R}$ \\
\hline Cephazolin & 30 & S & $\mathrm{S}$ & $\mathrm{S}$ & $\mathrm{S}$ & $\mathrm{S}$ & S & I & I & I \\
\hline Cephalothin & 30 & S & $\mathrm{S}$ & $\mathrm{S}$ & $\mathrm{S}$ & $\mathrm{S}$ & S & $\mathrm{R}$ & $\mathrm{R}$ & $\mathrm{R}$ \\
\hline Gentamicin & 120 & S & $\mathrm{S}$ & $\mathrm{S}$ & $\mathrm{S}$ & $\mathrm{S}$ & $\mathrm{S}$ & $\mathrm{S}$ & $\mathrm{S}$ & S \\
\hline Amikacin & 30 & S & $\mathrm{S}$ & $\mathrm{S}$ & $\mathrm{S}$ & $\mathrm{S}$ & S & $\mathrm{S}$ & $\mathrm{S}$ & S \\
\hline Amoxicillin-clavulanic acid & 30 & S & $\mathrm{S}$ & $\mathrm{S}$ & $\mathrm{S}$ & $\mathrm{S}$ & S & I & I & I \\
\hline Cefoxitin & 30 & S & $\mathrm{S}$ & $\mathrm{S}$ & $\mathrm{S}$ & $\mathrm{S}$ & S & $\mathrm{S}$ & S & S \\
\hline Ceftriaxone & 30 & S & $\mathrm{S}$ & $\mathrm{S}$ & $\mathrm{S}$ & $\mathrm{S}$ & S & $\mathrm{S}$ & $\mathrm{S}$ & S \\
\hline Ciprofloxacin & 5 & S & $\mathrm{S}$ & $\mathrm{S}$ & $\mathrm{S}$ & $\mathrm{S}$ & $\mathrm{S}$ & $\mathrm{S}$ & $\mathrm{S}$ & S \\
\hline Imipenem & 10 & S & $\mathrm{S}$ & $\mathrm{S}$ & $\mathrm{S}$ & $\mathrm{S}$ & $\mathrm{S}$ & $\mathrm{S}$ & $\mathrm{S}$ & $\mathrm{S}$ \\
\hline Trimethoprim-sulfamethoxazole & $1.25 / 23.75$ & S & $\mathrm{S}$ & $\mathrm{S}$ & $\mathrm{S}$ & $\mathrm{S}$ & $\mathrm{S}$ & $\mathrm{S}$ & $\mathrm{S}$ & S \\
\hline Chloramphenicol & 30 & S & $\mathrm{S}$ & $\mathrm{S}$ & $\mathrm{S}$ & $\mathrm{S}$ & $\mathrm{S}$ & $\mathrm{S}$ & $\mathrm{S}$ & S \\
\hline Kanamycin & 30 & S & $\mathrm{S}$ & $\mathrm{S}$ & $\mathrm{S}$ & $\mathrm{S}$ & S & $\mathrm{S}$ & $\mathrm{S}$ & S \\
\hline Tetracycline & 30 & S & $\mathrm{S}$ & $\mathrm{S}$ & $\mathrm{S}$ & $\mathrm{S}$ & $\mathrm{S}$ & $\mathrm{R}$ & $\mathrm{R}$ & $\mathrm{R}$ \\
\hline Trimethoprim & 5 & S & $\mathrm{S}$ & $\mathrm{S}$ & $\mathrm{S}$ & $\mathrm{S}$ & $\mathrm{S}$ & $\mathrm{S}$ & $\mathrm{S}$ & $\mathrm{S}$ \\
\hline Sulphonamide & 300 & S & $\mathrm{S}$ & $\mathrm{S}$ & $\mathrm{S}$ & $\mathrm{S}$ & $\mathrm{S}$ & $\mathrm{S}$ & $\mathrm{S}$ & $\mathrm{S}$ \\
\hline Ceftiofur & 30 & S & $\mathrm{S}$ & $\mathrm{S}$ & $\mathrm{S}$ & $\mathrm{S}$ & S & $\mathrm{S}$ & $\mathrm{S}$ & $\mathrm{S}$ \\
\hline Streptomycin & 10 & I & $\mathrm{I}$ & I & I & I & I & I & I & I \\
\hline Nalidixic acid & 30 & S & $\mathrm{S}$ & $\mathrm{S}$ & $\mathrm{S}$ & $\mathrm{S}$ & $\mathrm{S}$ & $\mathrm{R}$ & $\mathrm{R}$ & $\mathrm{R}$ \\
\hline Sulfamethoxole & 25 & $\mathrm{I}$ & $\mathrm{I}$ & I & I & I & I & $\mathrm{R}$ & $\mathrm{R}$ & $\mathrm{R}$ \\
\hline
\end{tabular}

$R$ Resistance, $I$ Intermediately resistance, $S$ Susceptible

Isolates were identified by serotyping; two of them $\left(\mathrm{A}_{1,2,3}\right.$ and $\left.\mathrm{B}_{1,2,3}\right)$ were found as $S$. Dublin and one $\left(\mathrm{C}_{1,2,3}\right)$ as $S$. Bredeney.

Disc diffusion method indicated that, $S$. Bredeney was found to be resistant to ampicillin, cephalothin, tetracycline, nalidixic acid and sulphamethoxazole. In addition, all $S$. Dublin A, B and $S$. Bredeney isolates were intermediately resistant to streptomycin, $S$. Dublin A and B to sulphamethoxazole and $S$. Bredeney to amoxicillin/clavulanic acid and cephazolin (Table 2).

\section{Discussion}

Increased prevalence in animal origin foods makes Salmonella very important for food safety and public health. So knowing more about its complex life cycle and identifying the regular distribution pattern of Salmonella in the internal organs became necessary. In the present study $1.6 \%(3 / 188)$ of the cattle bile samples were found to be contaminated with Salmonella. In a study in Brazil, from 18 gallbladder and 16 bile samples belong to 30 cattle Salmonella was isolated. In 11 samples Salmonella was detected from both gallbladder and bile samples (10). Previous studies revealed that gallbladder of cattle and sheep may be the site and the source for fecal shedding of important enteric foodborne pathogens, such as Salmonella spp. and Campylobacter spp. (5; 14). In addition Deng et al. (9) reported that the liver and spleen may be the primary sites for setting itself up as a commensa over a long time after oral challenge and the gallbladder may be considered as a potential source of Salmonella. The gallbladder is a frequent and an important site of S.Typhi, which is generally more numerous in the bile than in feces (31). Although in various studies it was reported that, gallbladder abnormalities and gallstones often associated with chronic carriage of Salmonella in gallbladder (23), in this study any abnormalities or gallstones were not detected in Salmonella positive bile's gallbladders.

In the present study, from all isolates $p h o P Q$ gene was detected by PCR. Van Velkinburgh and Gunn (32) suggested that Salmonella spp. can respond to bile to increase resistance and that this response likely includes proteins that are the members of PhoP regulon. These PhoP-PhoQ regulated products may play an important role in the survival of Salmonella spp. in the intestine or gallbladder.

In the current study out of the three Salmonella isolates two of them were identified as $S$. Dublin and one as $S$. Bredeney. The epidemiological importance of $S$. Dublin is its ability to cause subclinical persistent infection in cattle (24). It is possible that gallbladder and bile might be the reservoir of bacterium. Accordingly, these carriers can contaminate environment and other food animals.

However, $S$ Typhimurium or $S$. Enteritidis are the prevalent serotypes of invasive non-typhoidal salmonella disease, a case was reported with $S$. Dublin in Mali (28). $S$. Dublin is host adapted to cattle zoonotic bacterium can 
causes illness and septicaemia in human (21). In most reference laboratories $S$. Bredeney is an uncommon human pathogen. Although $S$. Bredeney accounts for a very small proportion of overall human infection, there are indications that it may achieve local importance in particular regions at specific times. In recent years $S$. Bredeney has become the third most common $S$. Enterica serotype among isolates from human infections submitted for identification to the National Salmonella Reference Laboratory in Ireland (7). Also in a study conducted in Turkey, $S$. Bredeney was one of the identified serotype in spices contaminated with Salmonella spp. (13).

There is worldwide concern that many bacteria, including Salmonella, are becoming resistant to antimicrobial agents. Trends in antimicrobial susceptibility patterns of Salmonella isolates are being monitored in different countries. In the United States, $84 \%$ of the Salmonella isolates from retail meats were resistant to at least one antibiotic, and $53 \%$ to at least three antibiotics (36). Salmonella isolated from meat products in Ireland were resistant to sulfamethoxazole and streptomycin with a rate of $86.3 \%$ and $80.9 \%$, respectively (11). Dias et al. (10) both cattle gallbladder and bile Salmonella isolates showed resistance to cephalothin, sulfazothrim and ampicillin. In the same study $50 \%$ of the Salmonella isolated from bile of cattle showed resistance to chloramphenicol. $6.25 \%$ of bile and $5.55 \%$ of gallbladder isolates were resistant to 12 antibiotics including amikacin, ampicillin, cephalothin, ceotaxime, ceftadizime, sulfazothrim, aztreonam, cefoxitin, ceftriaxone, chloramphenicol, gentamicin and tetracycline. In a different study between 2001 and $200479.6 \%$ of $S$. Dublin isolates from cattle were found resistant to ampicillin and $32.7 \%$ to trimethoprim-sulfamethoxazole (8).

In conclusion bile can be a site of Salmonella in cattle and all the isolates carried phoPQ gene which is required for increased bile resistance in Salmonella. Additionally, Salmonella isolates showed resistance to serious antibiotics. $S$. Bredeney showed resistance to antibiotics more than $S$. Dublin. Antibiotic resistant Salmonella where colonized in gallbladder or bile of cattle (chronic carriers) has an epidemiological impact.

\section{References}

1. Anon (1991): Dynabeads anti-Salmonella: For rapid selective enrichment of Salmonella. Dynal, A.S. Oslo, Norway, 1-2 (Manufacturer information).

2. Anon (2002): Microbiology of foods and animal feeding staff-horizontal method for the detection of Salmonella spp. International Standart (ISO, 6579).

3. Anon (2006): Clinical and Laboratory Standards Institute. Performance standards for antimicrobial susceptibility testing; sixteenth informational supplement. M100-S16 Vol.26 No.3.
4. Begley M, Gahan CGM, Hill C (2005): The interaction between bacteria and bile. FEMS Microbiol Rev, 29, 625651.

5. Buchwald DS, Blaser MJ (1984): A review of human salmonellosis. II. Duration of excretion following infection with nontyphi Salmonella. Rev Infect Dis, 6, 345-356.

6. Chandra M, Singh BR, Shankar H, Agarwal M, Agarwal RK, Sharma G, Babu N (2006): Study on prevalance of Salmonella infection in goats. Small Rum Res, 65, 24-30.

7. Cormican M, Delappe N, O'Hare C, Doran G, Morris D, Feeney G, Fanning S, Daly M, Fitzgerald M, Moorre J (2002): Salmonella enterica serotype Bredeney: Antimicrobial susceptibility and molecular diversity of isolates from Ireland and Northern Ireland. Appl Environ Microbiol, 68(1), 181-186.

8. Davis MA, Hancock DD, Besser TE, Daniels JB, Baker KNK, Call DR (2007): Antimicrobial resistance in Salmonella enterica serovar Dublin isolates from beef and dairy sources. Vet Microbiol, 119, 221-230.

9. Deng SX, Cheng AC, Wang MS, Cao P, Yan B, Yin NC, Cao SY, Zhang ZH (2008): Quantitative studies of the regular distribution pattern for Salmonella Enteritidis in the internal organs of mice after oral challenge by a specific real-time polymerase chain reaction. World $\mathrm{J}$ Gastroenterol, 14(5), 782-789.

10. Dias FS, dos Santos LF, Franco RM, Nascimento ER (2010): Antimicrobial resistance in Salmonella spp. isolated from cattle gallbladder slaughtered in the South of the state of Rio de Janeiro. R Bras Ci Vet, 17 (3/4), 104107.

11. Duffy G, Cloak OM, O'Sullivan MG, Guillet A, Sheridan JJ, Blair IS, McDowell DA (1999): The incidence and antibiotic resistance profiles of Salmonella spp. on Irish retail meat products. Food Microbiol, 16, 623-631.

12. Erol I, Hildebrandt G, Kleer J, Yurtyeri A (1999): Kopplung von Immunomagnetischer separation und Polymerase-kettenreaktion zum Schnellachweis von Salmonellen in Hackfleisch und Geflügelinnereien. Berl Münch Tieraerztl Wschr, 112, 100-103.

13. Erol I, Hildebrandt G, Goncuoglu M, Ormanci FSB, Yurtyeri A, Kleer J, Kuplulu O (2009): Incidence and serotype distribution of Salmonella in spices retailed in Turkey. Fleischwirtschaft International, 24(6), 50-52.

14. Ertas HB, Ozbey A, Kilic A, Muz A (2003): Isolation of Campylobacter jejuni and Campylobacter coli from the gall bladder samples of sheep and identification by polymerase chain reaction. J Vet Med B, 50, 294-297.

15. Fluit AC, Widjojoatmodjo MN, Box ATA, Torensma R, Verhoef J (1993): Rapid detection of Salmonella in poultry with the magnetic Immuno-Polymerase Chain Reaction assay. Appl Environ Microbiol, 59(5), 13421346.

16. Gay JM, Rice DH, Steiger JH (1994): Prevalence of faecal Salmonella shedding by cull dairy cattle marketed in Washington State. J Food Prot, 57, 195-197.

17. Goncuoglu M, Erol I, Ayaz ND, Ormanci FSB, Kaspar CW (2010): Isolation and genomic characterization of Escherichia coli O157:H7 in bile of cattle. Ann Microbiol, 60, 293-297. 
18. Gunn JS, Hohmann EL, Miller SI (1996): Transcriptional regulation of Salmonella virulence: a PhoQ periplasmic domain mutation results in increased net phosphotransfer to PhoP. J Bacteriol, 178, 6369-6373.

19. Gunn JS (2000): Mechanisms of bacterial resistance and response to bile. Microbes Infect, 2, 907-913.

20. Guo L, Lim K, Gunn JS, Bainbridge B, Darveau R, Hackett M, Miller SI (1997): Regulation of lipid A modifications by Salmonella Typhimurium virulence genes phoP-phoQ. Science, 276, 250-253.

21. Helms M, Vastrup P, Gerner-Smidt P, Mølbak K (2003): Short and long term mortality associated with foodborne bacterial gastrointestinal infections: registry based study. Br Med J, 326, 357-361.

22. Jeong KC, Kang MY, Heimke C, Shere JA, Erol I, Kaspar CW (2007): Isolation of Escherichia coli O157:H7 from the gall bladder of inoculated and naturally-infected cattle. Vet Microbiol, 119, 339-345.

23. Lai CW, Chan RCY, Cheng AFB, Sung JY, Leung JWC (1992): Common bile duct stones: a cause of chronic salmonellosis. Am J Gastroenterol, 87, 1198-1199.

24. Lomborg SR, Agerholm JS, Jensen AL, Nielsen LR (2007): Effects of experimental immunosuppression in cattle with persistently high antibody levels to Salmonella Dublin lipopolysaccharide O-antigens. BMC Vet Res, 3, 17.

25. Popoff MY (2001): Antigenic formulas of the Salmonella serovars. WHO Colaborating Centre for Reference and Research on Salmonella, Institute Pasteur, France.

26. Soto SM, Guerra B, Del Cerro A, González-Hevia MA, Mendoza MC (2001): Outbreaks and sporadic cases of Salmonella serovar Panama studied by DNA fingerprinting and antimicrobial resistance. Int $\mathrm{J}$ Food Microbiol, 71, 35-43.

27. Stoffregen WC, Pohlenz JFL, Dean-Nystrom EA (2004): Escherichia coli O157:H7 in the gallbladders of experimentally infected calves. J Vet Diagn Investig, 16, 79-83.

28. Tennant SM, Diallo S, Levy H, Livio S, Sow SO, Tapia M, Fields PI, Mikoleit M, Tamboura B, Kotloff KL, Nataro JP, Galen JE, Levine MM (2010): Identification by PCR of non-typhoidal Salmonella enterica serovars associated with invasive infections among febrile patients in Mali. PLoS Negl Trop Dis, 4(3), e621.
29. Thanassi DGL, Cheng W, Nikaido H (1997): Active efflux of bile salts by Escherichia coli. J Bacteriol, 179, 2512-2518.

30. Tsolis RM, Young GM, Solnick JV, Baumler AJ (2008): From bench to bedside: Stealth of enteroinvasive pathogens. Nat Rev Microbiol, 6(12), 883-892.

31. Vaishnavi C, Singh S, Kochhar R, Bhasin D, Singh G, Singh K (2005): Prevalence of Salmonella enterica serovar Typhi in bile and stool of patients with biliary diseases and those requiring biliary drainage for other purposes. Jpn J Infect Dis, 58, 363-365.

32. Van Velkinburgh JC, Gunn JS (1999): PhoP-PhoQ regulated loci are required for enhanced bile resistance in Salmonella spp. Infect Immun, 67, 1614-1622.

33. Walker RA, Lindsay E, Woodward MJ, Ward LR, Threlfall EJ (2001): Variation in clonality and antibioticresistance genes among multiresistant Salmonella enterica serotype Typhimurium phage type U302 (MR U302) from humans, animals and foods. Microb Drug Resist, 7, 13-21.

34. Way JS, Josephson KL, Pillai SD, Abbaszadagan M, Gesba CP, Pepper IL (1993): Specific detection of Salmonella spp. by multiplex polymerase chain reaction. Appl Environ Microbiol, 59, 1473-1479.

35. Wegner HC, Aarestrup FM, Gerner-Smidt $\mathbf{P}$, Bager $\mathbf{F}$ (1999): Transfer of antibiotic resistant bacteria from animals to man. Acta Vet Scand Suppl, 92, 51-57.

36. White DG, Zhao S, Sudler R, Ayers S, Friedman S, Chen S, McDermott PF, McDermott SD, Wagner D, Meng J (2001): The isolation of antibiotic-resistant Salmonella from retail ground meat. New Engl J Med, 345, 1147-1154.

37. Widjojoadmodjo MN, Fluit AC, Torensma R, Keller BH, Verhoef J (1991): Evaluation of the magnetic immuno-PCR assay for rapid detection of Salmonella. Eur J Clin Microbiol Infect Dis, 10(11), 935-938.

Geliş tarihi: 12.09.2012 / Kabul tarihi: 13.11.2012

Address for correspondence:

Irfan Erol, Ph.D., DVM

Professor in Food Hygiene and Microbiology

Ankara University, School of Veterinary Medicine,

Department of Food Hygiene and Technology, 06110,

Diskapi, Ankara, Turkey

e-mail:erol@veterinary.ankara.edu.tr 